Reviews

environmental change. The subfield of population geography is virtually defined as the study of human migration and geographic mobility; in the past decade economic, cultural and feminists geographers studying globalization and development has given close and critical attention in field studies to the roles of transmigration and transnationalism in the 'relationships between people and places.' The work of Victoria Lawson $(1998 ; 2000)$ is particularly notable in this regard.

Beyond significant theoretical and empirical contributions of geographers in the study of migration of all forms is the longstanding awareness among geographers of the need for disciplinary integration in the study of human-environmental interactions. Intellectual integration and synthesis is considered by many of us who teach the discipline at the collegiate level the analytic signature of the discipline. Among geographers Kevin McHugh (2000) has made a most clear and eloquent argument for interdisciplinary perspective, and also multi-method approach, in the study of migration, in his call for incorporating ethnography in the geographic analysis of migration and spatial processes:

Geographers - steeped in thinking in terms of space, place and connection - are well posed to explore and elucidate peoples, place and societal implications of migration and circulation systems. This challenge requires openness to multiple epistemologies and perspectives, as intellectual life across the social sciences and humanities is becoming increasingly defined by what Geertz (1983) term blurred genres in social thought. ... Cultivating ethnographic approaches will help enliven migration studies in geography and foster linkages with other branches of the discipline, opening up new vistas in migration, culture and society (pp. 85-86).

The editors of this good volume of theory and practice in migration scholarship would have done better to include the theoretical vantage and empirical insight of colleagues such as Lawson and McHugh in promoting conversation across social scientific disciplines about the study of migration.

\author{
References Cited: \\ Geertz, C. \\ 1983. Local knowledge: Further essays in interpretive anthropology. New York: Basic Books. \\ Lawson, V. \\ 1998. Hierarchical households and gendered migration: Feminists extensions to migration research. \\ Progress in Human Geography 22: 39-53. \\ Lawson, V. \\ 2000. Questions of migration and belonging: understandings of migration under neoliberalism in Ecuador. \\ International Journal of Population Geography 5: 261-276. \\ McHugh, K. \\ 2000. Inside, outside, upside down, backward, forward, round and round: A case for ethnographic studies \\ in migration. Progress in Human Geography 24: 71-89.
}

\title{
Indians, Merchants, and Markets: a Reinterpretation of the Repartimiento and Spanish- Indian Economic Relations in Colonial Oaxaca, 1750-1821. By Jeremy Baskes. Stanford, CA: Stanford University Press (2000), 306 pp.
}

\section{Reviewed by Jeffrey H. Cohen, Department of Anthropology, Pennsylvania State University}

Jeremy Baskes's Indians, Merchants, and Markets is an excellent addition to the history of colonial Mexico. His discussion of the colonial economy, Indian-Spanish relations and the role structure and meaning of the repartimiento should be welcomed by historians and anthropologists alike.

Baskes uses the production, trade and export of cochineal (a red dye made from the dried body of the beetle Dactylopius coccus, that grow on nopal cactus) as a lens through which to question long held assumptions about colonial Mexico's economy, the place of natives in that economy, and the role of the repartimiento. For the author, the colonial economy is not an isolated system built upon the needs and desires of colonial rulers, rather, it is part of a broad global trade network that brought cochineal dye (called grana) from native communities throughout rural 
Reviews

Oaxaca, Mexico to buyers throughout Europe. The native Oaxacan becomes an active agent (albeit an active agent working under serious constraints) who uses the household production of cochineal in concert with farming to make a better living. In this economy the repartimiento becomes more than a coercive force, it is in fact an important source for credit among peasant and Indian households and communities struggling to survive.

Baskes begins the book by posing a series of ideas concerning the repartimiento. He asks that the reader reject the traditional approach to the repartimiento that characterizes it as a system through which labor was forcible drawn from communities to provide tribute for the Spanish ruling class. The point is not that there were no abuses of the system, or that it lacked a coercive side, rather, Baskes effectively shows that Indians throughout rural Oaxaca sought repartimiento relationships as a way to gain credit (the only avenue to credit available) that could then be invested in crops, cochineal or goods. In fact, he points out that Indians often sought repartimiento relationships voluntarily as a way to gain goods and income. Thus, the relationships that existed between alcaldes and Indians, did not necessarily "drive" those natives into the economy, rather the relationships created a social contract between the two groups that typically left the Indian producer with a small profit. For example, producers of cochineal who entered repartimiento relationships with alcaldes (themselves often natives), typically had some of the dye left after their contracts were settled that they could then sell for additional income, or perhaps invest in the purchase of animals or the maintenance of the household. Baskes does not deny that there was coercion, and alcaldes coveted their positions and the incomes those positions generated. In fact, Baskes points out that there was often fierce competition for positions among the upper class. Nevertheless, he effectively shows how local producers also benefited from the relationships.

The benefits of these relationships extended beyond the economic as the repartimiento help stabilize prices through long term contracts and afforded a way for two very different populations (Spanish and native) to effectively communicate cross-culturally. Thus, what might seem to be price-fixing from one perspective, also served to ease negotiations between populations that were effectively alien to each other. Native producers were interested most in gaining a "just price" that is a price that covered production expenses, a concept very different than one based on the value of time and more importantly profit. For the Alcaldes, who were installed under the pretext that they would protect the Crown's interests, cochineal was a good investment, and one that would cover the short fall in Spain's rather meager compensation. Nevertheless, dealing in cochineal was not without risks. In fact, the last chapters of the book focus on the market for cochineal, its shifts and swings, the risks that faced exporters and the role the dye played in broader market systems.

Baskes's work is all the more satisfying given contemporary trends in Oaxaca's economy. Anyone who is familiar with the state and its many crafts and traditional arts will recognize local models of contemporary production in this discussion of cochineal. Contemporary artisans often organize production around putting-out systems where patrons supply materials and designs in exchange for finished goods that are sold on international markets (Cook and Binford 1990; Littlefield 1978). Like their ancestor, today's craftsmen and women are often at the mercy of the price a patron will pay. Like their ancestors, they turn to these patrons for loans and credit. And as with their ancestors, what can be a coercive system is also an avenue for household maintenance and sometimes profit (for example, see my discussion of contemporary weaving in Santa Ana del Valle, in Cohen 1999:48-52). Last, but certainly not least, cochineal is making something of a comeback and is now an integral part of the textile making traditions and marketing rhetoric practiced in many communities. Typically households have a nopal patch where they cultivate the cochineal beetle. When visitors arrive, they demonstrate how to get the rich red/purple dye from the dried crushed body of the insect. The dye becomes part of the pitch and authenticity of the wares that are for sale. The structure of this production, based as it is in household gardens and that can be tended in conjunction with farming, wage labor and so forth has changed very little from the model presented by Baskes (pp. 18-19).

Some readers might ask why anyone should focus on something as mundane as cochineal in a place so removed from the centers of power as Oaxaca. In fact, these are two of the best reasons to pick up this book. The discussion of local economies and global trade, of native producers and their relationships to colonial rulers and of the repartimiento's role in production, trade and social organization of rural Oaxaca during the later colonial period should remind readers of the framework developed by Eric Wolf Europe and the People Without History (1982) and Sidney Mintz's in Sweetness and Power (1985). Both authors ask that we break down categorical constructions like modern and traditional and explore the interactions between systems, and through which these systems are created. Oaxaca often seems about as far as can be from the modern (or even colonial) centers of power, and the role of cochineal production in global trade is easy to overlook in most discussions of Mexico's colonial economy. Nevertheless, like sugar for Mintz, cochineal production established powerful bonds between native and Spanish society and economy, linking rural producers to merchants in London in profound ways. Cochineal's rise and fall as a commodity has much to offer those of us who study contemporary crafts from anthropological perspectives. For historians, the book is a reminder of the wealth of information that can be found in small places. Baskes is to be 
Reviews

commended for this well written, informative and lively account of the repartimiento.

\section{References Cited:}

Cohen, Jeffrey H.

1999. Cooperation and Community: Economy and Society in Oaxaca. Austin: University of Texas Press.

Cook, Scott and L. Binford.

1990. Obliging Need: Rural Petty Industry in Mexican Capitalism. Austin: University of Texas Press.

Littlefield, Alice.

1978. Exploitation and the Expansion of Capitalism: The Case of the Hammock Industry of Yucatan.

American Ethnologist 5:495-508.

Mintz, Sidney.

1985. Sweetness and Power: The Place of Sugar in Modern History. New York: Penguin Books.

Wolf, Eric R.

1982. Europe and the People Without History. Berkeley: University of California Press.

\section{Naming the Enemy: Anti-Corporate Movements Confront Globalization, by Amory Starr, London: Zed Books (2000), xvi, 268 pp..}

\section{Reviewed by David Skidmore, Department of Politics and International Relations, Drake University, Des Moines, IA.}

Despite, or perhaps because of, its wild diversity, the anti-globalization movement has in recent years emerged as a force with which to be reckoned. Leaders of the major institutions of global economic governance, including the World Trade Organization (WTO), the International Monetary Fund (IMF), the World Bank and the G-8, can find practically no city in the world where meetings will not be plagued by rowdy demonstrations and the scent of tear gas. Pressure from anti-globalization non-governmental organizations (NGOs) played a role in the failure of the Multilateral Agreement on Investment (MAI) negotiations, the collapse of efforts to launch a new "millennium round" of global trade negotiations and resistance in the United States congress to granting President Clinton unfettered fast track trade negotiating authority. The anti-sweatshop movement has harried Nike and a number of other corporations into promising improvements in labor conditions at the factories that produce their goods. Protests stemming from the Shell Oil Company's alleged complicity with government repression in Nigeria forced Shell to develop a new corporate code of conduct regarding human rights issues. A number of other firms have followed suit. The list of these and other recent successes is impressive.

Yet the anti-globalization movement has thus far mostly focused on slowing the juggernaut of corporate globalization and resisting the most egregious of governmental and corporate abuses. What has yet to emerge is a coherent and widely accepted vision of an alternative future. Amory Starr's provocative book surveys and assesses both the concrete goals and the philosophical worldviews that animate many of the groups involved in the struggle to craft an alternative to globalization as it is currently taking shape.

This is not simply another review of "the debate" over globalization. Starr accepts without question the damning critiques of globalization that have originated with others. Her focus is on the varieties of resistance to globalization and where they may lead. Globalization itself is treated as symptomatic of a deeper and more insidious disease; namely, the domination of modern political, economic and cultural life by large, powerful, globe-spanning corporations. Big business firms serve as the "agents" of globalization and should, in Starr's view, be considered the primary targets of popular resistance.

Starr's survey of more than a dozen distinct popular social movements assesses the degree to which each places anti-corporate motivations at the center of its ideology and strategic vision. In keeping with the book's rather 